\title{
Culture of benthic diatom Nitzschia sp. with macroalgae carriers and its application as feed of juveniles Stichopus japonicus
}

\author{
Aili Jiang ${ }^{*}$ (E) Heng Ji, Hengxu Liu, Huimin Zhu, Guofeng Ai and Xiaochen Guo
}

\begin{abstract}
Carrier culture is the combination of suspension culture and adherent culture. Carriers could be used to improve the culture efficiency of large-scale culture of adherent benthic diatom. In order to identify a suitable carrier for mass suspension culture of the benthic diatoms Nitzschia sp. powders of seven macroalgae were used as carriers for diatom attachment including U/va pertusa, degummed Laminaria japonica, Sargassum muticum, Chaetomorpha valida, Zostera marina, Sargassum fusiforme and Sargassum thunbergii. Diatoms could grow on the surface of the suspended carriers and could effectively utilize the nutrients released by the decomposition of these carriers. Among the seven carriers, Ulva pertusa powder was the most effective for Nitzschia culture when comprehensively considering the nutrition of the harvested diatoms and nutrient utilization of the algae carrier by diatoms. The seaweed powder was dried at $80^{\circ} \mathrm{C}$ before used as carrier, this process should meet the sterilization requirements for microalgal culture and is easy to implement in the large-scale cultivation of diatoms. Diatoms cultured with carriers were used to feed juveniles Stichopus japonicus with a wet weight of $5.0 \pm 2.0 \mathrm{~g}$, as well as diatoms cultured using conventional methods without carriers, and no significant differences were observed between the two kinds of feed. Compared to sea cucumbers fed with commercial feed, the growth rate of S. japonicus fed with carrier-cultured diatoms was approximately 1.5 times greater, and the activities of non-specific immune enzymes were improved in the coelomic fluid including acidic phosphatase, alkaline phosphatase and superoxide dismutase. Feeding sea cucumber with fresh diatoms could effectively reduce the total nitrogen and total phosphorus in the culture water, improve the water quality, and promote the breeding of sea cucumbers, regardless of whether the carrier culture was adopted.
\end{abstract}

Keywords: Nitzschia sp., Carrier, Culture, Feed, Stichopus japonicus

\section{Background}

The sea cucumber Apostichopus japonicus has become one of the most important fishery resources in Asia, especially in China. Industrial aquaculture methods for sea cucumbers are being rapidly developed, in which artificial feed (formulated diets) are needed [1]. Feed is a key factor in the culture of sea cucumbers. A. japonicus has a wide range of food sources, such as animal and plant detritus, microorganisms and the excrement of other

*Correspondence: jal9035@163.com

College of Life Science, Yantai University, Yantai 264005, Shandong, China animals. The usual feed used in the culture of A. japonicus is a mixture of powdered macroalgae and sea mud [2]. The main function of sea mud is thought to be to provide diatoms [3], but the quantity of diatoms in sea mud cannot meet the nutrient demand of sea cucumber, so a large amount of macroalgal powder should be input as nutrient, which may pose an environmental risk from uneaten or undigested food [2]. Therefore, it is critical to identify substitutes for the macroalgae and sea mud in order to meet the nutritional needs of sea cucumbers.

Live diatoms are a potential alternative, which are rich in protein, fatty acids, trace elements and other nutrients, and are commonly used as fresh food for fish, shellfish,

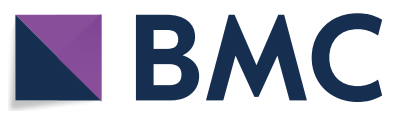

(c) The Author(s) 2020. This article is licensed under a Creative Commons Attribution 4.0 International License, which permits use, sharing, adaptation, distribution and reproduction in any medium or format, as long as you give appropriate credit to the original author(s) and the source, provide a link to the Creative Commons licence, and indicate if changes were made. The images or other third party material in this article are included in the article's Creative Commons licence, unless indicated otherwise in a credit line to the material. If material is not included in the article's Creative Commons licence and your intended use is not permitted by statutory regulation or exceeds the permitted use, you will need to obtain permission directly from the copyright holder. To view a copy of this licence, visit http://creativeco mmons.org/licenses/by/4.0/. 
shrimp, and in particular, their larvae. In the aquaculture of abalone, sea urchin, sea cucumber, and other economically important marine animals, diatoms could be used as live food for various stages of growth [4-6]. As living food, diatoms have the potential to regulate water quality, control nutrient levels in water, reduce the occurrence of animal diseases [6], and have been widely used in the aquaculture of abalone, sea urchins, and sea cucumbers in China, Japan, and Chile.

The culture of planktonic microalgae has developed from batch-culture to semi-continuous and fully continuous culture, from manual culture to semi-automatic and even fully automatic continuous culture [7-9]. Most diatoms have the ability to secrete extracellular polymers [10], the adhesive properties of these polymers make it difficult to realize the large-scale cultivation of benthic diatoms using semi-continuous and continuous culture technology, as well as the harvest of benthic diatoms [11]. Developing a large-scale, high-density cultivation approach and convenient harvest method for benthic diatoms is important for the aquaculture of economically marine animals.

At present, corrugated plates are used as carriers in the cultivation of benthic diatoms, which are used directly for attachment of the larvae of abalone or sea cucumber after diatoms attached. The main disadvantages of this method are the large water requirement and poor biomass production [12]. Carrier culture is the combination of suspension culture and adherent culture, and is widely used for the culture of various cell types, including microalgae. [13]. Microalgae are attached to the surface of carriers so that it can be suspended in water, the microalgae density can be highly concentrated and the microalgae can be easily harvested [14].

The selection of attachment substrate by diatoms is not strictly specific. In nature, macroalgae is a common attachment substrate for epiphytic diatom, and harvested seaweed is also a common food source for cultivation of sea cucumber. Powders of macroalgae added to the culture system could be used as the attachment carrier for diatom cells. The carriers provide a large adhesion area for diatoms growth, and can remain suspended through continuous agitation during culture to ensure the material exchange between microalgae and the environment. Compared with the traditional culture using corrugated plate, this approach is expected to increase the density of benthic diatoms [15].

Microalgae are autotrophic organisms that absorb inorganic nutrients and convert them into organic compounds, and could serve as biofilters for the nutreints leaching from the dried macroalgae [16]. A combination of microalgae and macroalgae should provide a balanced diet, adhesive culture of diatom with macroalgae powder as carrier is theoretically feasible. In order to provide a large-scale and high-density culture technology for benthic diatoms, several types of macroalgal powders were used as carriers for diatom culture. The cultivated diatoms and the macroalgae carriers were harvested as a whole, which is more conducive to healthy growth of the sea cucumber and does not damage the water quality and the bottom quality. The cultivated diatoms and macroalgae carriers could be directly used as fresh bait for aquaculture, or combined with other ingredients into various kinds of composite aquaculture feed. The study will have great practical significance for the aquaculture industry.

\section{Methods \\ Materials}

The benthic diatom Nitzschia sp. was provided by the Laboratory of Algae Biotechnology of Yantai University.

Seven kinds of macroalgae were selected as carriers for culture of benthic diatoms, including Ulva pertusa, degummed Laminaria japonica, Sargassum muticum, Chaetomorpha valida, Zostera marina, Sargassum fusiforme, and Sargassum thunbergii, which were commonly used as raw ingredients for sea cucumber feed. The dried macroalgae were provided by Qingdao Great Haidi Feed Co. Ltd, and were pulverized into ultra-fine pieces $(<75 \mu \mathrm{m})$, and then dried thoroughly at $80^{\circ} \mathrm{C}$.

Seawater was collected from a clean area of the Bohai Sea in the Yantai region and used after deposition treatment and filtration by grit and a $0.45-\mu \mathrm{m}$ membrane. The treated seawater had a $\mathrm{pH}$ of 7.5-7.9 and salinity of approximately $32 \%$.

Commercial feed (formulated diets) for sea cucumber was purchased from Qingdao Great Haidi Feed Co. Ltd. and contained $15 \%$ protein, $2-5 \%$ crude fat, $10 \%$ coarse fiber, and $45 \%$ crude ash, which was used as a ference diet in sea cucumber feeding test.

\section{Treatment of carriers}

Three different methods were used to process the carriers:

A. $0.1 \mathrm{~g}$ seaweed powder and $300 \mathrm{ml}$ M Guillard's $\mathrm{F} / 2$ culture medium $(\mathrm{M}-\mathrm{f} / 2$ substrate)with silicate were sterilized separately at $121{ }^{\circ} \mathrm{C}$ for $30 \mathrm{~min}$, and were then mixed after cooling.

B. $0.1 \mathrm{~g}$ seaweed powder was added to $300 \mathrm{ml} \mathrm{M-f/2}$ substrate with silicate. The mixture was sterilized at $121{ }^{\circ} \mathrm{C}$ for $30 \mathrm{~min}$ and was used in diatom culture after cooling.

C. $300 \mathrm{ml} \mathrm{M-f/2} \mathrm{substrate} \mathrm{with} \mathrm{silicate} \mathrm{was} \mathrm{sterilized} \mathrm{at}$ $121{ }^{\circ} \mathrm{C}$ for $30 \mathrm{~min}$ and was then supplemented with $0.1 \mathrm{~g}$ dried macroalga powder after cooling. 
The $\mathrm{pH}$ of the medium was adjusted to $7.5-7.9$ before used in diatom culture.

\section{Diatom cultivation}

Culture medium $(300 \mathrm{ml})$ was prepared according to the methods described above, and was added to $500-\mathrm{ml}$ conical flasks. Diatom seed liquid were prepared in $500 \mathrm{~mL}$ sterilized flasks with $\mathrm{M}-\mathrm{f} / 2$ substrate at $21-23{ }^{\circ} \mathrm{C}$ under illumination intensity of $3000 \mathrm{~lx}\left(42 \mu \mathrm{E} \mathrm{m}^{-2} \mathrm{~s}^{-1}\right)$ for $24 \mathrm{~h}$ on end. When reaching at log phase, the seed liquid was inoculated with $10 \%(\mathrm{v} / \mathrm{v})$ into the medium. The diatoms were cultured at $21-23{ }^{\circ} \mathrm{C}$ in an oscillating incubator under continuous shaking at $120 \mathrm{r} / \mathrm{min}$ for $24 \mathrm{~h}$ at continuously illumination intensity of $3000 \mathrm{~lx}$.

Three parallel cultures were set for every experiment, and diatom cultures without microalgal carrier were used as control. Throughout culturing, the growth and attachment of diatoms were observed daily using regular microscopy, and culturing was ended when the diatoms began to detach from the carrier.

After cultivation, the culture solution was centrifuged at $8000 \mathrm{r} / \mathrm{min}$ for $20 \mathrm{~min}$ to obtain the harvest containing diatoms and carriers, which were then washed twice with deionized water. The wet weight, total nitrogen (TN), total phosphorus (TP), protein, and polysaccharide contents were determined, as well as the content of total $\mathrm{N}$ and total $\mathrm{P}$ in the water after centrifugation.

\section{Sea cucumber feeding test}

Juvenile Stichopus japonicus were provided by Oriental Ocean Technology Co. Ltd. All animals used in this experiment were of the same batch. The sea cucumbers were acclimated to laboratory conditions after placement in square concrete tanks $(2 \times 2 \times 1.5 \mathrm{~m})$ for at leat 15 days. The animals were cultured in the laboratory at room temperature $\left(15-18{ }^{\circ} \mathrm{C}\right)$ until the start of the experiments and fed formulated diet every 2 days at a ratio of $3 \%$ of the animals' total fresh weight (W/W). Individuals with adequate physical strength (good stretching ability and pointed parapodium) and similar wet weights $(5.0 \pm 2.0 \mathrm{~g})$ were selected for feeding experiments, the selected sea cucumbers were randomly assigned to each experimental group.

The experiments were conducted in plastic aquariums $(100 \mathrm{~cm}$ in diameter and $80 \mathrm{~cm}$ in height, with a depth of $60 \mathrm{~cm}$ water) that were sterilized with potassium permanganate $\left(\mathrm{KMnO}_{4}\right)$ before the seawater was injected. A special frame with polyethylene corrugated plates was placed in each aquarium and was used for the attachment of sea cucumbers. The temperature and salinity of the water were controlled and ranged from $15-18{ }^{\circ} \mathrm{C}$ and $29-33 \%$, respectively. Sunshade nets were set above the aquariums in order to avoid the harm of direct sunlight to the sea cucumber, and every aquarium was continuously aerated through two air vents to maintain the dissolved oxygen value between $5.3 \mathrm{mg} / \mathrm{L}$ and $7.10 \mathrm{mg} / \mathrm{L}$.

Four experimental feeding groups were set according to their diet: (1) diatoms cultured with Ulva carrier (group I), Ulva powder (group II), diatoms cultured without carrier (group III), and commercial feed (group IV). Three replicates were used for each treatment group, each containing 30 sea cucumbers.

Sea cucumbers were fed with feed (3\% of animals' total fresh weight, W/W) every morning and evening (9:00AM and 5:00PM). The feed was dispersed evenly into each tank after immersing with seawater. Residual feed was siphoned off, and $1 / 3$ of the water was replaced every day to maintain water cleanliness. The frame was replaced every 15 days. The total $\mathrm{N}$ and $\mathrm{P}$ contents of the aquaculture water were measured every five days (before water replacement) throughout a 60 -day feeding period. The ingestion status and mortalities of the animals were recorded daily.

\section{Sample collection and measurement}

After the feeding experiment, all of the sea cucumbers were subject to a starvation period of $48 \mathrm{~h}$, and then all individuals were removed to a clean cystosepiment to stretch naturally. Their body length and body mass were measured, and the animals were dissected in order to collect their body wall, intestines, and coelomic fluid. The weight of the body wall and the weight and length of the intestines as well as their biochemical compositions were determined to calculate the weight gain rate, specific growth rate, feed efficiency, ratio of visceral weight to body wall weight, ratio of intestine weight to body wall weight, and ratio of intestine length to body length. After drying at $65{ }^{\circ} \mathrm{C}$ to a consistent weight, the biochemical composition of the body wall was also analyzed.

The activities of acid phosphatase (ACP), alkaline phosphatase (AKP), and superoxide dismutase (SOD) in the coelomic fluid were determined, and the intestinal tract was immediate deep frozen and preserved at $-80{ }^{\circ} \mathrm{C}$ until the activities of amylase (AMS), cellulase, and protease were determined.

\section{Determination methods}

The Kjeldahl method was applied to determine the total nitrogen $(\mathrm{N})$ content in the algae harvest which was expressed in terms of the weight of nitrogen per gram of harvest (mg/g wt). Total phosphorus (P) in the havest was detected using ammonium molybdate spectrophotometric method after digested with $\mathrm{H}_{2} \mathrm{SO}_{4}$ and was expressed as the weight of phosphorus per gram of havest $(\mathrm{mg} / \mathrm{g}$ $w t)$. 
The total nitrogen and total phosphorus contents in the water were measured according to the technical specifications in the manual "Criterion of Ocean Investigation" [17].

The increase of $\mathrm{N}$ and $\mathrm{P}(\Delta \mathrm{N}$ and $\Delta \mathrm{P}, \mathrm{g})$ in the algal harvest were calculated as follows:

$$
\begin{aligned}
& \Delta N=T N_{1} \times m_{1}-\mathrm{TN}_{2} \times m_{2} \\
& \Delta P=T P_{1} \times m_{1}-\mathrm{TP}_{2} \times m_{2}
\end{aligned}
$$

where $\mathrm{TN}_{1}$ and $\mathrm{TP}_{1}$ are the contents of total nitrogen and total phosphorus in the harvest after culture (mg/g wt), $\mathrm{TN}_{2}$ and $\mathrm{TP}_{2}$ are the total nitrogen and total phosphorus contents in the carrier materials ( $\mathrm{mg} / \mathrm{g}$ dry weight), $\mathrm{m}_{1}$ is the wet weight $(\mathrm{g})$ of the havest obtained after culture, and $m_{2}$ is the dry weight ( $\mathrm{g}$ ) of the seaweed carrier.

A Vario EL III Element Analyzer (Elementar Analysensysteme $\mathrm{GmbH}$, Hanau, Germany) was used to measure the nitrogen content in the body walls, and the protein content was calculated as $\mathrm{N} \times 6.25$. Fat concentration was determined using the Soxhlet extraction method, and ash content was assayed after heated for $10 \mathrm{~h}$ in an SX-2.5-10 N muffle furnace (Shanghai, China) at $400{ }^{\circ} \mathrm{C}$.

Growth indices of sea cucumbers were calculated as follows:

The final weight: $W_{f}(g)=\frac{T_{w}}{N_{f}}$, where $T_{w}$ is the final total weight of each individual, and $N_{f}$ is the number that survived at the end of the experiment.

Survival rate $(S R): \operatorname{Sr}(\%)=\frac{100 \times N_{f}}{N_{i}}$, where $N_{f}$ and $N_{i}$ are the final and initial numbers of sea cucumbers, respectively.

Weight growth rate $(W G R): W G R(\%)=\frac{W_{t}-W_{0}}{W_{0}} \times 100$

Special growth rate $\left(S G R ; \% \mathrm{~d}^{-1}\right): S G R=\frac{100 \times\left(\operatorname{In} W_{t}-\operatorname{In} W_{0}\right)}{t}$

Feed efficiency $(F E): F E(\%)=100 \times \frac{W_{t}-W_{0}}{F}$

Ratio of visceral weight to body wall weight $(V B R)$ :

$$
\operatorname{VBR}(\%)=\frac{W_{v}}{W_{b}} \times 100
$$

Ratio of intestine weight to body wall weight (IBR) :

$$
\operatorname{IBR}(\%)=\frac{W_{i}}{W_{b}} \times 100
$$

Ratio of intestine length to body length $(I B L)$ :

$$
\operatorname{IBL}(\%)=\frac{L_{i}}{L_{b}} \times 100
$$

where $W_{t}$ and $W_{0}$ are the average body wet weight at the end and beginning of the experiment, respectively, and $t$ is the duration of the experiment. $\mathrm{F}$ is the quantity of feed. $W_{v}, W_{b}$ and $W_{i}$ are the wet weights of the viscera, body wall, and intestines, respectively. $L_{i}$ and $L_{b}$ are the lengths of the intestines and bodies, respectively, of the sea cucumbers.

The activities of ACP, AKP, SOD, amylase, protease, and cellulase in coelomic fluid as well as protein contents were detected with corresponding kits purchased from the Nanjing Jiancheng Bioengineering Institute, these included an acid phosphatase assay kit, an alkaline phosphatase assay kit, a superoxide dismutase (SOD) assay kit, an amylase assay kit, a protease assay kit, and a cellulase (CL) test kit.

\section{Statistical analyses}

SPSS 17.0 software was used for all statistical analyses. One-way ANOVAs and T-tests were used for the comparative analyses. $P$ values less than 0.05 were considered statistically significant.

\section{Results}

\section{Growth state of Nitzschia}

Nitzschia was cultured in media prepared according to method $\mathrm{C}$ described above, and Fig. 1 showed the microscopic observations of the diatoms at different culture stages. The macroalgae carriers showed a regular shape and darker color at the early stage of cultivation, and that a small number of diatoms were scattered in the water as observed in the field of vision.

As the culture progressed, diatoms gradually aggregated around the carriers and grew on them (in the middle and late stage of culture), and the edges of the seaweed carriers gradually blurred and the color gradually lightened. During the final growth period (approximately 7 days), diatoms began to dissociate from the carriers. Diatoms on the macroalgal carriers gradually reduced, and most of the carriers became more transparent, indicating that they had decomposed.

To facilitate harvesting of the diatoms, a culture time of 6 days was used in subsequent experiments. At this timepoint, most diatoms were still attached to or aggregated on the carrier, forming large clusters of diatoms, which was conducive for harvesting.

\section{Effects of macroalgae carriers on the culture of diatoms} Nitzschia was cultured in media prepared according to method $\mathrm{C}$ with 7 different macroalgal powders as carriers. Figures 2 and 3 display the final concentrations of 


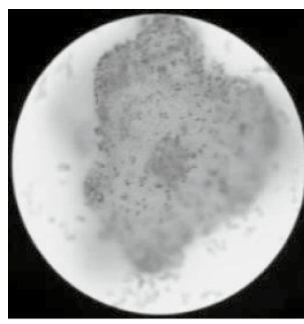

Initial stage

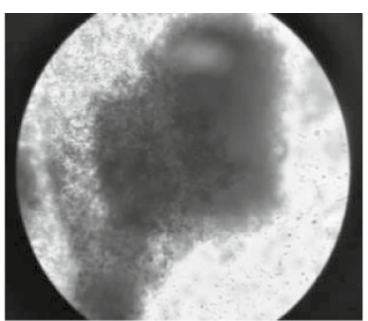

Middle stage

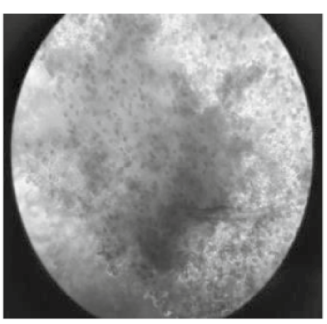

Later period

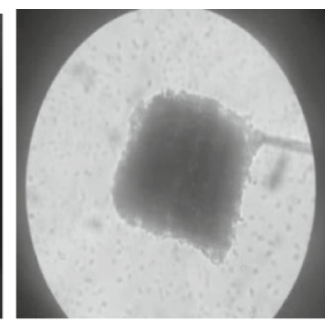

Final stage

Fig. 1 Growth of diatoms during culture

total nitrogen and phosphorus in the water and algal harvest, respectively.

The contents of nitrogen and phosphorus in the $\mathrm{M}-\mathrm{f} / 2$ medium were $12.321 \mathrm{mg} / \mathrm{L}$ and $1.086 \mathrm{mg} / \mathrm{L}$, respectively. After culturing, the control group cultured without carriers displayed significantly lower concentrations of total nitrogen and phosphorus than those of the initial $\mathrm{M}-\mathrm{f} / 2$ medium $(p<0.05)$, while higher levels were observed in the experimental groups with different seaweed carriers (Fig. 2). Microscopic observations also showed that the intracellular contents of the seaweed carriers gradually dissolved during the culture process, suggesting decomposition of the carriers to various degrees. The total nitrogen concentrations in the culture water were significantly higher in the groups cultured with Sargassum muticum, Sargassum thunbergii, and degummed Laminaria japonica than those of other groups $(p<0.05)$, while the total phosphorus concentrations were higher

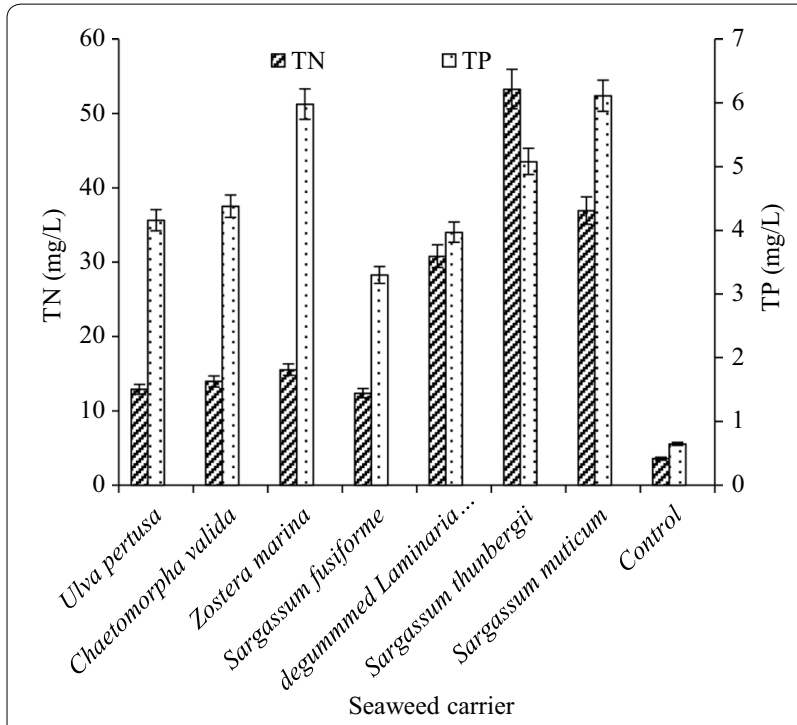

Fig. 2 Total nitrogen and phosphorus concentrations in water upon completion of culture in the groups cultured with Zostera marina, Sargassum muticum, and Sargassum thunbergii $(p<0.05)$. Our results indicate that the macroalgae differ in their degree of decomposition and the substances released after decomposition.

In the diatom culture system that included Ulva pertusa as the carrier, the increase of $\mathrm{N}$ and $\mathrm{P}(\Delta \mathrm{N}$ and $\Delta \mathrm{P}$, g) in the algal harvest were significantly greater than those of the control without carrier $(p<0.01)$ and the other experimental groups $(p<0.01)$, while the final concentrations of nitrogen and phosphorus in the water were lower in the Ulva-treated group than in the other experimental groups (excluding the Sargassum fusiforme-treated group), indicating that the nitrogen and phosphorus generated by the decomposition

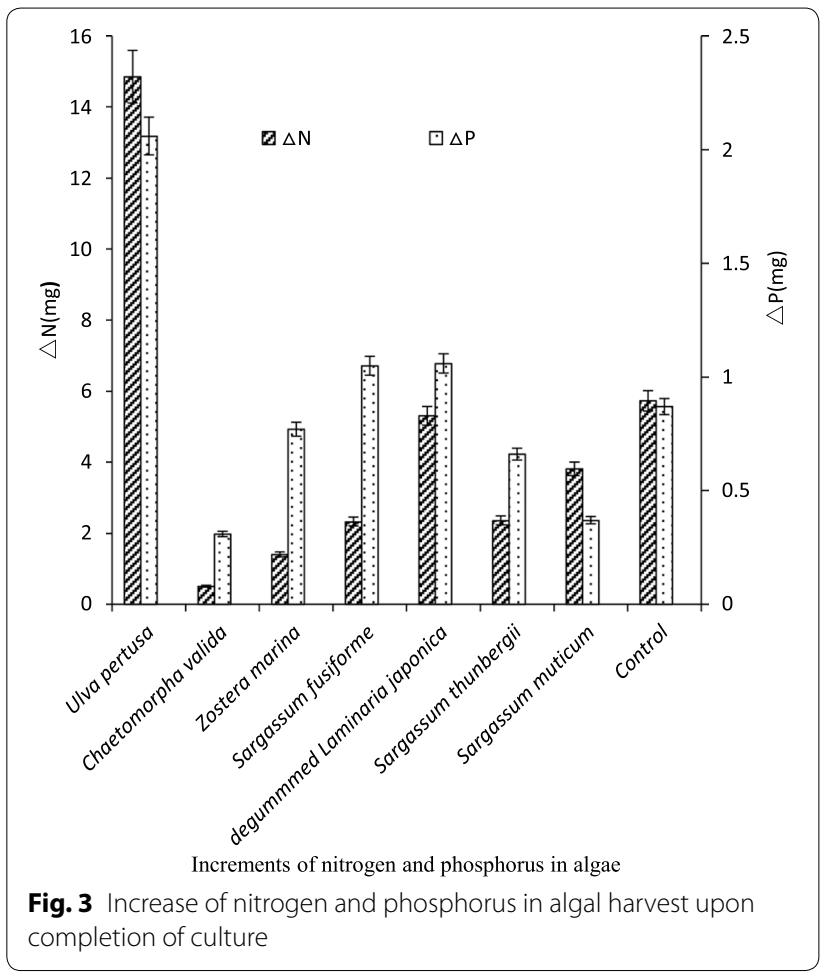


of Ulva could be quickly utilized by the diatoms for growth.

In the groups treated with degummed kelp and Sargassum fusiforme, the increases in phosphorus in the algal mud were greater than that of the control group $(p<0.05)$. The increase in nitrogen in the control group was greater than that of the Sargassum fusiforme-treated group $(p<0.05)$ but was similar to that of degummed kelp-treated group $(p>0.05)$. The final concentrations of nitrogen and phosphorus in the water of the degummed kelp-treated group were significantly higher than that of the control group $(p<0.05)$. The final nitrogen concentration in the water of the Sargassum fusiforme-treated group was significantly lower than that of the degummed kelp-treated group $(p<0.05)$ and nearly equal to that of the $\mathrm{M}-\mathrm{f} / 2$ medium $(p>0.05)$, but the final phosphorus concentration was higher than that of the $\mathrm{M}-\mathrm{f} / 2$ medium $(p<0.01)$ and lower than that of the degummed kelptreated group $(p<0.05)$.

In the Sargassum muticum- and Sargassum thunbergii-treated groups, the increases in nitrogen and phosphorus in the algal harvest were significantly less than that of the control group $(p<0.05)$, and the final concentrations of nitrogen and phosphorus in water were significantly higher than the initial value $(p<0.05)$ and those of the control group $(p<0.05)$. Using Chaetomorpha valida as carrier, the increases in nitrogen and phosphorus in the algal harvest were significantly less than that of the control group $(p<0.01)$, while the final concentrations of nitrogen and phosphorus in the water were similar to that of the Ulva-treated group $(p>0.05)$ and significantly higher than that of the control group $(p<0.01)$.

The results indicated that the diatoms should utilize the nutrients released by the macroalgae carriers and the utilization was different among seven carriers during culture. When compared with these seven macroalgae on a comprehensive basis, Ulva appears to be the most favorable carrier for the culture of diatoms.

\section{Effect of carrier treatment on diatom culture}

Figure 4 shows the effects of three treatment methods on the cultivation of diatoms. The greatest increases of nitrogen and phosphorus in the algal harvest were achieved when the Ulva powder was treated according to method $C$, somewhat higher than the group that the carrier was treated using method A $(p>0.05)$ and method B $(p<0.05)$, respectively. When Ulva powder was treated according to method $\mathrm{A}$, the concentrations of nitrogen and phosphorus in the culture water were similar to those of the group that the carrier was treated using method C $(p>0.05)$, and lower than that of the group treated the carrier according to method B $(p<0.05)$. When the Ulva

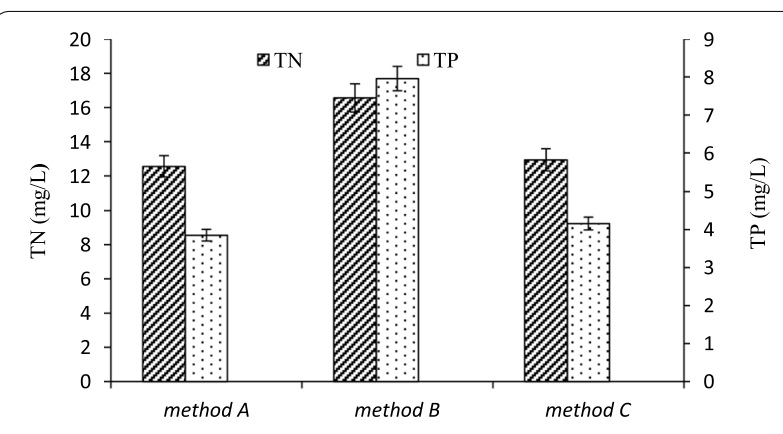

(1) Total nitrogen and phosphorus concentrations in water upon completion of culture

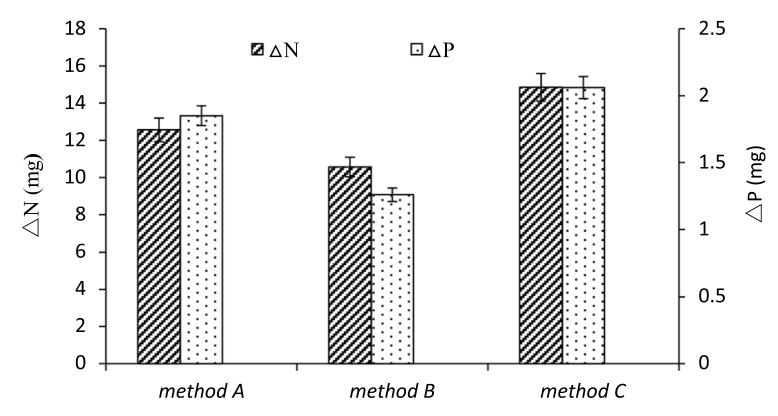

(2) Increases in nitrogen and phosphorus in algal mud upon completion of culture

Fig. 4 Effects of carrier treatment methods on diatom culture. Method A: Ulva powder and M-f/2 culture medium were sterilized separately at $121^{\circ} \mathrm{C}$ for $30 \mathrm{~min}$.. Method B: Ulva powder and M-f/2 culture medium were mixed and then sterilized at $121^{\circ} \mathrm{C}$ for $30 \mathrm{~min}$. Method C: Ulva powder was added to sterilized $\mathrm{M}-\mathrm{f} / 2$ culture medium after drying at $80^{\circ} \mathrm{C}$

powder was treated using method B, the concentrations of nitrogen and phosphorus in the water were significantly higher than for the other two methods $(p<0.05)$, but the algal harvest was less $(p<0.05)$. Compared with the other two methods, method $\mathrm{C}$ is the most favorable for diatom culture because it is easy to implement in production and is more suitable for large-scale cultivation of diatoms.

\section{Effect of feed on the growth of juvenile sea cucumbers}

As shown in Table 1, the survival rates of juvenile sea cucumbers fed with four types of feed were all greater than 95\%, with little difference observed among feed $(p>0.05)$. The final weight, WGR, and SGR of juvenile sea cucumbers fed with two types of diatoms (diatom culture with or without carrier) were significantly greater than those of the commercial feed group $(p<0.05)$. The feed efficiencies of the four diets displayed a similar trend. Among the four feeding groups, the sea cucumber fed with Ulva powder had the greatest VBR, IBR, and LBL, and the IBR and LBL were significantly different from the other three groups $(p<0.05)$. The VBR, IBR, and LBL 
Table 1 Effects of four types of feed on the growth of juvenile sea cucumbers $(n=15)$

\begin{tabular}{lcccc}
\hline Bait & $\begin{array}{l}\text { Group I } \\
\text { Diatoms cultured } \\
\text { with Ulva }\end{array}$ & $\begin{array}{l}\text { Group II } \\
\text { Ulva powder }\end{array}$ & \multicolumn{1}{l}{$\begin{array}{l}\text { Group III } \\
\text { Diatoms cultured } \\
\text { without carrier }\end{array}$} & $\begin{array}{l}\text { Group IV } \\
\text { Commercial bait }\end{array}$ \\
\hline Survival rate (SR, \%) & $98.88 \pm 0.37$ & $95.55 \pm 0.75$ & $98.88 \pm 0.46$ & $97.78 \pm 0.44$ \\
Final weight (Wt, g) & $15.23 \pm 1.12^{\mathrm{a}}$ & $8.06 \pm 0.95^{\mathrm{c}}$ & $15.56 \pm 1.23^{\mathrm{a}}$ & $11.01 \pm 1.03^{\mathrm{b}}$ \\
Weight growth rate (WGR, \%) & $144.67 \pm 7.76^{\mathrm{a}}$ & $61.24 \pm 8.10^{\mathrm{c}}$ & $151.21 \pm 7.54^{\mathrm{a}}$ & $100.22 \pm 7.94^{\mathrm{b}}$ \\
Special growth rate (SGR; \% d $\mathrm{d}^{-1}$ ) & $1.49 \pm 0.09^{\mathrm{a}}$ & $0.80 \pm 0.08^{\mathrm{c}}$ & $1.54 \pm 0.11^{\mathrm{a}}$ & $1.16 \pm 0.12^{\mathrm{b}}$ \\
Feed efficiency (FE, \%) & $85.32 \pm 6.42^{\mathrm{a}}$ & $43.25 \pm 4.35^{\mathrm{c}}$ & $87.65 \pm 7.15^{\mathrm{a}}$ & $78.64 \pm 6.54^{\mathrm{b}}$ \\
Ratio of visceral weight to body wall weight (VBR, \%) & $17.52 \pm 0.93$ & $19.34 \pm 1.12$ & $17.44 \pm 0.87$ & $18.15 \pm 1.02$ \\
Ratio of intestine weight to body wall weight (IBR, \%) & $4.15 \pm 0.21$ & $5.03 \pm 0.33^{\mathrm{a}}$ & $4.16 \pm 0.25$ & $4.32 \pm 0.19$ \\
Ratio of intestine length to body length (IB, \%) & $4.27 \pm 0.15$ & $5.33 \pm 0.17^{\mathrm{a}}$ & $4.25 \pm 0.11$ & $4.37 \pm 0.16$ \\
\hline
\end{tabular}

In the same row, values with the same superscripts or no superscripts are not significantly different $(p>0.05)$, while distinct superscripts signify significant differences between values $(p<0.05)$

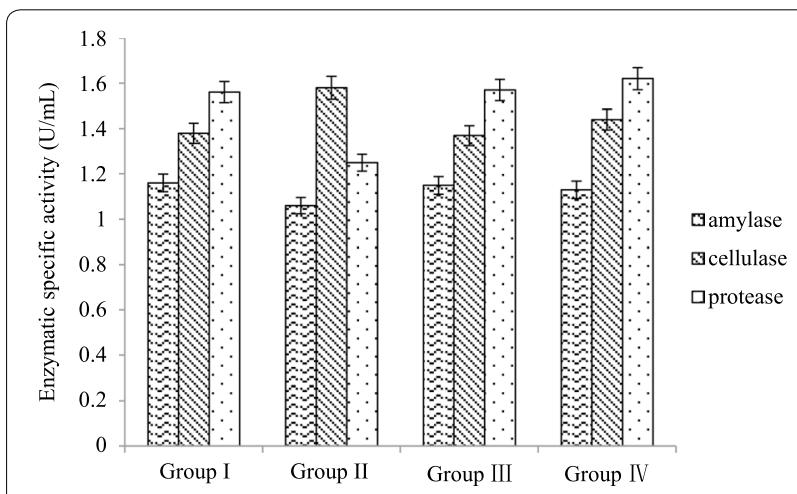

Fig. 5 Effects of four types of feed on the activities of digestive enzymes from juvenile sea cucumbers. In Groups I, II, III, and IV, sea cucumbers were fed diatoms cultured with UIva, Ulva powder, diatoms cultured without carriers, and commercial feed, respectively

of the two diatom feeding groups were slightly less than those of the commercial feed group $(p>0.05)$.

\section{Effect of feed type on the activities of digestive enzymes from juvenile sea cucumbers}

The effects of different feed on the activities of intestinal digestive are summarized in Fig. 5. No significant differences were observed in the activities of amylase, cellulose, and protease in the intestines of juvenile sea cucumbers $(p>0.05)$ upon completion of the feeding experiment. The activities of the three digestive enzymes in the two groups fed with diatoms showed little difference when compared to the animals fed with commercial feed, while the activities of amylase and protease were slightly greater than those fed with Ulva powder $(p>0.05)$, and cellulase activity was less than that of the group fed with Ulva powder $(p>0.05)$.

\section{Effect of feed type on the activities of non-specific immune enzymes}

The effects of feed type on the activities of several nonspecific immune enzymes in the coelomic fluid of juvenile sea cucumbers are summarized in Table 2. Similar to digestive enzymes, the activities of these enzymes in the sea cucumbers fed with diatoms were slightly greater

Table 2 Effects of four types of feed on the non-specific immune enzymes of juvenile sea cucumbers $(n=15)$

\begin{tabular}{lccrc}
\hline Bait & $\begin{array}{l}\text { Group I } \\
\text { Diatom cultured with Ulva }\end{array}$ & $\begin{array}{l}\text { Group II } \\
\text { Ulva powder }\end{array}$ & $\begin{array}{l}\text { Group III } \\
\text { Diatoms cultured } \\
\text { without carrier }\end{array}$ & $\begin{array}{l}\text { Group IV } \\
\text { Commercial bait }\end{array}$ \\
\hline ACP (U/mg pr) & $55.56 \pm 3.24^{\mathrm{a}}$ & $42.35 \pm 3.15^{\mathrm{b}}$ & $55.12 \pm 2.98^{\mathrm{a}}$ & $52.18 \pm 4.26^{\mathrm{a}}$ \\
AKP (U/mg pr) & $4.35 \pm 0.69^{\mathrm{a}}$ & $2.96 \pm 0.58^{\mathrm{b}}$ & $4.55 \pm 0.72^{\mathrm{a}}$ & $4.01 \pm 0.65^{\mathrm{a}}$ \\
SOD (U/mg pr) & $42.18 \pm 2.15^{\mathrm{a}}$ & $35.78 \pm 2.26^{\mathrm{b}}$ & $43.25 \pm 2.57^{\mathrm{a}}$ & $40.98 \pm 2.67^{\mathrm{a}}$ \\
GSH-Px (U/mg pr) & $123.56 \pm 3.33^{\mathrm{a}}$ & $98.62 \pm 3.01^{\mathrm{c}}$ & $125.78 \pm 2.98^{\mathrm{a}}$ & $115.34 \pm 3.15^{\mathrm{b}}$ \\
\hline
\end{tabular}

In the same row, values with the same superscripts or no superscripts are not significantly different $(p>0.05)$, while distinct superscripts signify significant differences between values $(p<0.05)$ 
Table 3 Effects of four types of feed on the biochemical components of juvenile sea cucumbers $(n=15)$

\begin{tabular}{llrrr}
\hline Bait & $\begin{array}{l}\text { Group I } \\
\text { Diatoms cultured with Ulva }\end{array}$ & $\begin{array}{l}\text { Group II } \\
\text { Ulva powder }\end{array}$ & $\begin{array}{l}\text { Group III } \\
\text { Diatoms cultured } \\
\text { without carrier }\end{array}$ & $\begin{array}{l}\text { Group IV } \\
\text { Commercial bait }\end{array}$ \\
\hline Protein (\%) & $33.08 \pm 1.25$ & $30.96 \pm 0.98$ & $33.14 \pm 0.99$ & $32.96 \pm 1.06$ \\
Lipid (\%) $^{\mathrm{a}}$ & $4.79 \pm 0.65$ & $4.16 \pm 0.58$ & $4.82 \pm 0.63$ & $4.96 \pm 0.62$ \\
Ash (\%) & $56.54 \pm 2.78$ & $56.86 \pm 2.53$ & $56.46 \pm 2.64$ & $56.49 \pm 2.34$ \\
Water (\%) & $91.32 \pm 3.12$ & $91.36 \pm 3.01$ & $91.05 \pm 2.61$ & $90.96 \pm 2.47$ \\
\hline
\end{tabular}

a Protein and lipid content are exprerssed as the dry basis

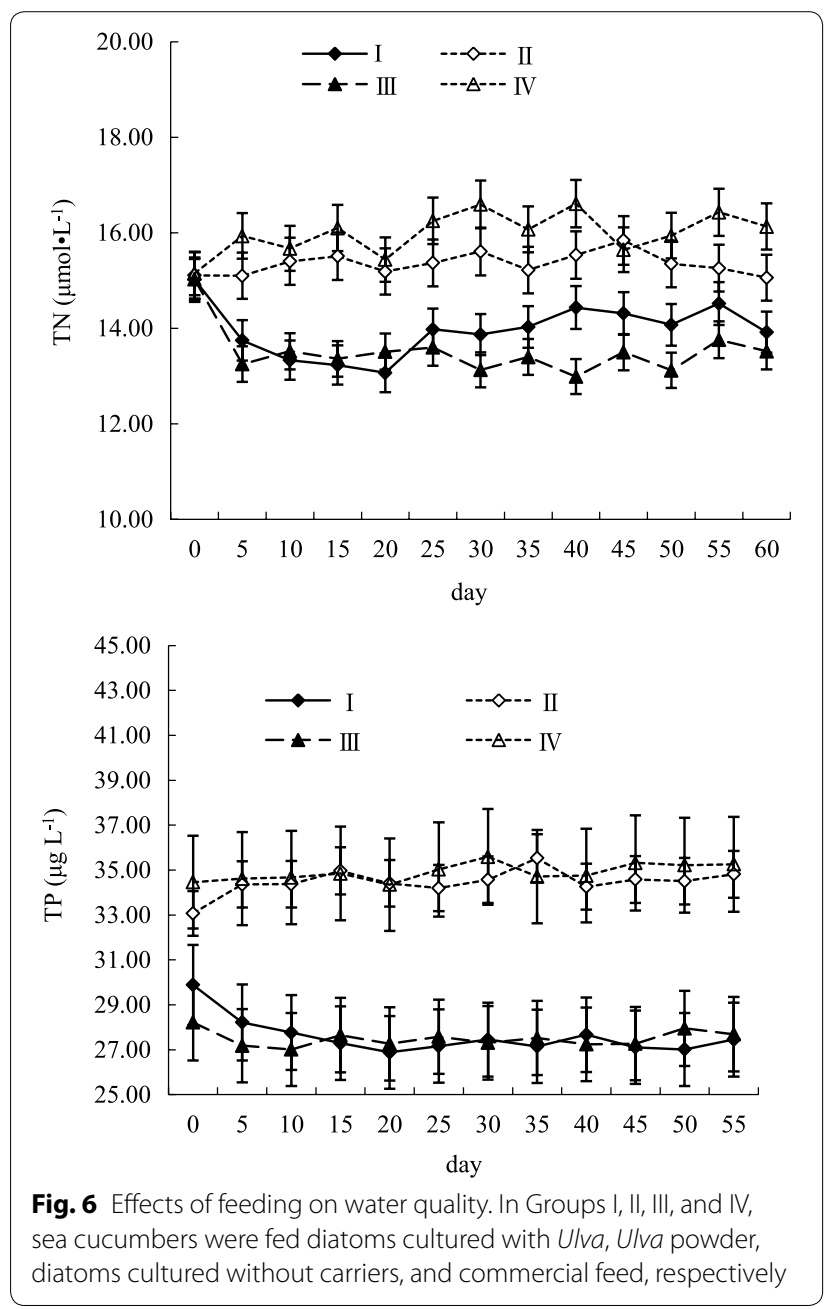

and were significantly greater than those of the Ulva feeding group $(p<0.05)$.

\section{Effects of feed type on biochemical components of juvenile sea cucumbers \\ The effects of feed type on the biochemical components of juvenile sea cucumbers are summarized in Table 3. The biochemical components exhibited no significant}

differences $(p>0.05)$ among the animals fed with diatoms cultured with or without carriers and commercial feed. However, protein and lipid contents were slightly less in the juvenile fed with Ulva $(p<0.05)$.

\section{Effects of feed type on water quality}

As shown in Fig. 6, when animals were fed with the two types of diatoms cultured with or without carriers, the total nitrogen and phosphorus in the aquaculture water were maintained at low levels because the elements could be absorbed by the large number of living algae in the system. However, the nitrogen and phosphorus levels in the water were significantly higher in the groups fed with commercial feed and Ulva powder $(p<0.05)$.

\section{Discussion}

The growth of benthic diatoms is often assessed using the microcount method following suspension of algal cells. However, in our experiments, diatoms were attached to the surface of carrier, and it is difficult to separate a large number of overlapping algal cells using conventional methods, which results in inaccurate counts. The levels of proteins, polysaccharides, and other macromolecules can also be used as indicators of microalgal growth and can be determined after crushing and extraction by freeze-thawing or ultrasonic methods, but it is difficult to determine the attribution of macromolecules due to the difficulty in separating microalgae and algal carriers. The presence of carriers made cell fragmentation more difficult and prevented complete extraction of proteins and other macromolecules. In addition, large amounts of extracellular polysaccharides (EPS) are secreted during the growth of benthic diatoms, and the amount of EPS and protein secreted are significantly affected by the diatom growth period, cell density, cell growth rate, and environmental factors $[18,19]$. Therefore, these secreted factors cause greater error when using polysaccharide or protein levels as indices to assess diatom growth [20].

The total nitrogen and phosphorus concentrations in the algal harvest could be determined after the oxidative 
digestion of organic matter, which was not disturbed by the extraction. In the process of diatom culture, the macroalgae carrier decomposed and released nutrients, which reduced the nitrogen and phosphorus levels of the carrier. Diatoms absorbed nutrients in the water and converted them into their own biomass, which increased the nitrogen and phosphorus content in the harvest. In this experiment, the algal harvest containing diatoms and macroalgae residue was used as a whole as feed of sea cucumber, so the composition was evaluated as a whole. Increases in nitrogen and phosphorus should be used as a visual indicator of diatom growth along with changes in the levels of dissolved nutrients in the water.

Macroalgae can release a large amount of nutrients in various forms (solution, granular, and colloidal) during death and decomposition [21], which can increase nitrogen and phosphorus levels in the water [22, 23]. In the process of growth and reproduction, microalgae can absorb a large amount of nutrient salts from the water in the form of ions (such as soluble orthophosphates) and colloids. The nitrogen and phosphorus nutrients in this experiment were added once prior to inoculation with microalgae, and the culture medium was not replenished during the culture process. The nitrogen and phosphorus nutrients in the culture medium were gradually utilized by diatoms and converted into microalgal biomass; thus, the levels of nitrogen and phosphorus in the water in the control group without carriers decreased continuously during culture. When the seaweed carrier was added into the culture system, nitrogen and phosphorus levels increased, indicating decomposition of the macroalgae. Microscopic observation also demonstrated that during the culture process, the seaweed was degraded and its intracellular contents were dissolved.

Varied effects of different macroalgae were observed on the growth of diatoms. As shown in Table 4, the nitrogen and phosphorus contents of several carriers were quite different, indicating that different nutrients were released

\begin{tabular}{llll}
$\begin{array}{l}\text { Table } 4 \text { Nitrogen } \\
\text { seaweeds }\end{array}$ & and & phosphorus & content in seven \\
\hline Macroalgae & $\mathbf{P}(\mathbf{m g} / \mathbf{g})$ & $\mathbf{N}(\mathbf{m g} / \mathbf{g})$ & Ratio of N and P \\
\hline Ulva & 4.397 & 33.187 & 16.713 \\
Cladophora & 4.712 & 25.020 & 11.757 \\
Sargassum muticum & 6.993 & 31.143 & 9.861 \\
Degummed kelp & 4.794 & 31.823 & 14.699 \\
Sargassum thunbergii & 4.116 & 41.349 & 22.244 \\
Cystophyllum & 5.712 & 66.855 & 25.917 \\
Zosteramarina & 6.520 & 41.685 & 14.157
\end{tabular}

during decomposition. In addition, other substances are also likely to be released during algal decomposition that inhibit or promote the growth of diatoms [24]. Using microscopic observation, we observed varied changes in the different carriers throughout the culture process, as well as in the decomposition rate of macroalgae.

For example, the decomposition rates of Sargassum thunbergii and Sargassum fusiforme were relatively fast, and the edges of the macroalgae became invisible after only three days, which was not conducive to the attachment of diatoms. The decomposition of Chaetomorpha valida was slow, and the release of intracellular substances likely takes at least 5-7 days, resulting in nitrogen and phosphorus levels too low to meet the needs of diatoms in culture.

From the perspective of diatom growth, the appropriate macroalgal carrier should have a moderate decomposition speed, the nitrogen and phosphorus released by decomposition should be at levels suitable for the growth of diatoms. Additionally, diatoms should be able to easily adhere to the surface of the carrier. Among the seven seaweeds used in this experiment, Ulva pertusa was the most suitable for the cultivation of diatoms and could effectively increase the diatom biomass. Additionally, Ulva itself is a good raw material for aquatic feed.

The main purpose of culture medium sterilization in microalgae culture is to kill protozoans, most protozoans can be killed when subjected to temperatures of $40-50{ }^{\circ} \mathrm{C}$ for 5-10 $\mathrm{min}$ [25]. The seaweed used in this experiment was dried at $80^{\circ} \mathrm{C}$, which was sufficient to kill protozoans in the carriers and can destroy algal cell walls to facilitate the dissolution of intracellular nutrients. Sterilization at $120{ }^{\circ} \mathrm{C}$ also facilitates the release of intracellular nutrients, but faster nutrient release speeds at higher temperature leading to high concentrations of nitrogen and phosphorus in the culture solution. The algal powder also tended to aggregate after sterilization at $120{ }^{\circ} \mathrm{C}$. All of these factors could affect the growth of diatoms.

Sterilization of seaweed powder and culture medium mixture at $120{ }^{\circ} \mathrm{C}$ promoted the release of intracellular substance, the excessive decomposition of the carrier was not conducive to diatom adhesion. Method C, seaweed powder was dried at $80{ }^{\circ} \mathrm{C}$ and the liquid medium was sterilized at $121{ }^{\circ} \mathrm{C}$ separately, this method should resulted in sufficient sterilization for diatom culture, and is easy to implement in a production environment. It is more suitable for the mass cultivation of diatom.

The adherent growth of diatoms results in low utilization of space, and makes it difficulty in the production and cultivation of benthic diatoms on a large scale. Adding carriers to the culture system could increase the available surface area for diatom attachment, and made it 
possible for the diatom to float under aeration, thus effectively increasing the space utilization and growth of the microalgae.

Adherence to the surface of carriers also facilitates the harvest of diatom, because the diatoms could gather into pieces to form a larger floating area in the water. We also observed significantly lower concentrations of total nitrogen and total phosphorus in the water of the group fed with diatoms cultured with carriers than in that of the group fed with commercial feed. Using living diatoms as feed could regulate culture environments, and reduce the occurrence of animal diseases.

The fresh feed obtained from carrier culture was rich in diatom, its rich nutrition could effectively promote the growth of aquaculture organisms. Many of the growth indices of juvenile sea cucumbers fed with diatoms on carriers were higher than those fed with commercial feed; the differences in VBR, IBR, and LBL indicated that diatoms cultured with carriers were easier to digest and could promote the growth of sea cucumbers 1.5-fold more than commercial feed. In addition, the activities of several non-specific immune enzymes in juvenile $S$. japonicus were all greater than those of the group fed with commercial feed, indicating that the feed could effectively improve the immunity of cultured organisms and enhance their disease resistance.

\section{Conclusion}

The characteristics of adherent growth of benthic diatoms make it difficult to cultivate on a large scale. In the carrier cultivation model, benthic diatoms could attach on the surface of macroalgae powder to improve the space utilization, and utilize the nutrients released by macroalgae carrier to increase their biomass. Drying Ulva powder at $80{ }^{\circ} \mathrm{C}$ should meet the sterilization requirements for microalgal culture, which is easy to implement in production and is suitable for the mass culture of diatoms. Feeding juvenile sea cucumbers with diatoms cultured with Ulva powder could effectively promote the growth of sea cucumbers and enhance the immunity of the animals.

\section{Acknowledgements}

We are grateful to a number of assistants who helped in the field work.

\section{Authors' contributions}

AJ designed the experimental scheme and did most of the writing, $\mathrm{HJ}$ carried out the culture of diatom, $\mathrm{HL}$ and $\mathrm{HZ}$ carried out the feeding experiment of sea cucumber, GA and XG helped with the interpretation of the results. All authors read and approved the final manuscript.

\section{Funding}

This study was supported by National Natural Science Foundation of China (No. 31070368, 41906102, 31572622) and Yantai Key Research and Development Plan (2018ZHGY062).

\section{Availability of data and materials}

The datasets used and/or analysed during the current study are available from the corresponding author on reasonable request.

\section{Ethics approval and consent to participate}

This study does not involve human participants, animals followed all applicable international and national guidelines for use of animals in research. All authors have consented to participate.

\section{Consent for publication}

Not applicable.

\section{Competing interests}

The authors declare that they have no competing interests.

Received: 20 November 2019 Accepted: 8 October 2020

Published online: 16 October 2020

\section{References}

1. Jiamin $\mathrm{S}$, Libin Z, Yang $\mathrm{P}$, et al. Feeding behavior and digestive physiology in sea cucumber Apostichopus japonicus. Physiol Behav. 2015;139:336-43. https://doi.org/10.1016/j.physbeh.2014.11.051.

2. Ce S, Shuanglin D, Fang W, et al. Effects of the sizes of mud or sand particles in feed on growth and energy budgets of young sea cucumber (Apostichopus japonicus). Aquaculture. 2015;440:6-11. https://doi. org/10.1016/j.aquaculture.2015.01.028.

3. Gao Q, Wang Y, Dong S, et al. Absorption of different food sources by sea cucumber Apostichopus japonicus (Selenka) (Echinodermata: Holothuroidea): evidence from carbon stable isotope. Aquaculture. 2011;319:272-6. https://doi.org/10.1016/.aquaculture.2011.06.051.

4. Nguyen DQD, Francis DS, Southgate PC. The nutritional value of live and concentrated micro-algae for early juveniles of sandfish Holothuria scabra. Aquaculture. 2017;473:97-104. https://doi.org/10.1016/j.aquac ulture.2017.01.028.

5. Scholtz R, Bolton JJ, Macey BM. Effects of different microalgal feeds and their influence on larval development in the white-spined sea urchin Tripneustes gratilla. Afr J Mar Sci. 2013;35(1):25-34. https://doi. org/10.2989/1814232X.2013.769902.

6. Zupo V, Glaviano F, Caramiello D, et al. Effect of five benthic diatoms on the survival and development of Paracentrotus lividus post-larvae in the laboratory. Aquaculture. 2018;495:13-20. https://doi.org/10.1016/j.aquac ulture.2018.05.028.

7. Gruber-Brunhumer M, Nussbaumer M, Jerney J, et al. Two-stage cultivation of N-rich and N-deprived Acutodesmus obliquus biomass: Influence of cultivation and dewatering methods on microalgal biomass used in anaerobic digestion. Algal Res. 2016;17:105-12. https://doi.org/10.1016/j. algal.2016.04.016.

8. Klassen V, Blifernez-Klassen O, Hoekzema Y, et al. A novel onestage cultivation/fermentation strategy for improved biogas production with microalgal biomass. J Biotechnol. 2015;215:44-51. https://doi.org/10.1016/j.jbiot ec.2015.05.008.

9. Milhazes-Cunha $\mathrm{H}$, Otero A. Valorisation of aquaculture effluents with microalgae: the integrated multi-trophic aquaculture concept. Algal Res. 2017;24:416-24. https://doi.org/10.1016/j.algal.2016.12.011.

10. Aslam SN, Strauss J, Thomas DN, et al. Identifying metabolic pathways for production of extracellular polymeric substances by the diatom Fragilariopsis cylindrus inhabiting sea ice. ISME J. 2018;12(5):1237-51. https://doi. org/10.1038/s41396-017-0039-z.

11. de Vree JH, Bosma R, Wieggers R, et al. Turbidostat operation of outdoor pilot-scale photobioreactors. Algal Res. 2016;18:198-208. https://doi. org/10.1016/j.algal.2016.06.006.

12. Bautista-Teruel MN, Maquirang JRH, dela Pena MR, et al. Use of agarbound microparticulate diet as alternative food for tropical abalone, 
Haliotis asinina (Linnaeus 1758) post-larvae in large-scale cultures. Aquacult Int. 2017;25(3):1239-52. https://doi.org/10.1007/s10499-017-0110-9.

13. Zhuang $L, Y u D$, Zhang J, et al. The characteristics and influencing factors of the attached microalgae cultivation : a review. Renew Sustain Energy Rev. 2018;94:1110-9. https://doi.org/10.1016/j.rser.2018.06.006.

14. Gross M, Zhao X, Mascarenhas V, Wen Z. Effects of the surface physicochemical properties and the surface textures on the initial colonization and the attached growth in algal biofilm. Biotechnol Biofuels. 2016;38(9):1-14. https://doi.org/10.1186/s13068-016-0451-z.

15. Zhang $Q$, Wang $L$, Yu ZG, et al. Pine sawdust as algal biofilm biocarrier for wastewater treatment and algae-based byproducts production. J Clean Prod. 2020;256:1-14. https://doi.org/10.1016/j.jclepro.2020.120449.

16. Li-hong C, Rong-lian X, Ai-li J, et al. A preliminary study on the potential value of a novel integrated aquaculture system on water purification. Aquacult Int. 2016;24:879-92. https://doi.org/10.1007/s1049 9-015-9958-8.

17. State Oceanic Administration of China. Technical regulations of marine chemical survey. Beijing: Maritime Press; 2006.

18. Pierre G, Graber M, Rafiliposon BA, et al. Biochemical composition and changes of extracellular polysaccharides (ECPS) produced during microphytobenthic biofilm development (Marennes-Ol, ron, France). Microb Ecol. 2012;63(1):157-69. https://doi.org/10.1007/s00248-011-9959-8.

19. Rong-lian X, Chang-hai W, Xue-bin C, et al. The potential value of different species of benthic diatoms as food for newly metamorphosed sea urchin Strongylocentrotus intermedius. Aquaculture. 2007;263:142-9. https://doi. org/10.1016/j.aquaculture.2006.10.003.

20. Lopes DC, Maurer JBB, Stevan-Hancke FR, et al. Chemical analysis of exopolysaccharide fractions and lipid compounds of the microalga Heterosigma akashiwo grown in vitro. Bot Mar. 2012;55(6):565-80. https ://doi.org/10.1515/bot-2012-0126.
21. García-Robledo E, Corzo A. Effects of macroalgal blooms on carbon and nitrogen biogeochemical cycling in photoautotrophic sediments: an experimental mesocosm. Mar Pollut Bull. 2011;62(7):1550-6. https://doi. org/10.1016/j.marpolbul.2011.03.044.

22. Bittick SJ, Sutula M, Fong P. A tale of two algal blooms: Negative and predictable effects of two common bloom-forming macroalgae on seagrass and epiphytes. Mar Environ Res. 2018;140:1-9. https://doi.org/10.1016/j. marenvres.2018.05.018.

23. Xufeng M, Xiaoyan W, Donghai Y, et al. An ecological-network-analysis based perspective on the biological control of algal blooms in Ulansuhai Lake. China Ecol Model. 2018;386:11-9. https://doi.org/10.1016/j.ecolm odel.2018.07.020.

24. Andrianasolo EH, Haramaty L, Vardi A. Apoptosis-inducing galactolipids from a cultured, marine diatom Phaeodactylum tricornutum. J Nat Prod. 2008;71(7):1197-201. https://doi.org/10.1021/np800124k.

25. Garcia-Cruz NU, Vigueras G, Pacheco-Lopez NA, et al. Effect of o-chlorophenol concentration on biomass during sulfate-reduction dechlorination in two different systems. Biochem Eng J. 2018;139:117-22. https://doi. org/10.1016/j.bej.2018.08.014.

\section{Publisher's Note}

Springer Nature remains neutral with regard to jurisdictional claims in published maps and institutional affiliations.
Ready to submit your research? Choose BMC and benefit from:

- fast, convenient online submission

- thorough peer review by experienced researchers in your field

- rapid publication on acceptance

- support for research data, including large and complex data types

- gold Open Access which fosters wider collaboration and increased citations

- maximum visibility for your research: over $100 \mathrm{M}$ website views per year

At BMC, research is always in progress.

Learn more biomedcentral.com/submissions 